\title{
Personality traits, difficulties in emotion regulation and academic satisfaction in a sample of argentine college students
}

\author{
Personalidad, dificultades en la regulación emocional y \\ satisfacción académica en una muestra de estudiantes \\ universitarios argentinos
}

\author{
Mario Trógolo ${ }^{\underline{\underline{\underline{\Xi}}}, \mathrm{a}}$, Leonardo Adrián Medrano ${ }^{\mathrm{a}}$ \\ a \\ Laboratorio de Psicología Cognitiva. Facultad de Psicología, Universidad Nacional de Córdoba, Argentina
}

\begin{abstract}
In recent years academic satisfaction in college students has been subject of considerable research, analysis and theorizing among educational researchers. The purpose of the current study was to examine the contributions of personality traits, using the Big Five Factor Model, and difficulties in emotion regulation to predict academic satisfaction in a sample of university students in Cordoba, Argentina. Contrary to expectations, results of hierarchical regression analysis showed that neither the Big Five traits nor difficulties in emotion regulation made a significantly contribution to the prediction of academic satisfaction. However when considering the overall profile of personality and emotion regulation, two subgroups theoretically and empirically consistent with significant differences in academic satisfaction were identified. Results, implications and limitations of the current study are discussed.
\end{abstract}

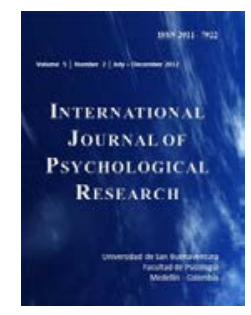

\section{RESUMEN}

En los últimos años la satisfacción académica ha sido un tema de considerable investigación debido a la incidencia de esta variable sobre el comportamiento de los estudiantes. El presente trabajo tuvo por objetivo examinar la contribución de los rasgos de personalidad y la regulación emocional en la predicción de la satisfacción académica de los estudiantes universitarios de la ciudad de Córdoba. Contrariamente a lo esperado, los resultados obtenidos mediante análisis de regresión múltiple jerárquica mostraron que ni los rasgos de personalidad ni las dimensiones de regulación emocional predijeron en forma significativa la satisfacción académica. Sin embargo, al considerar el perfil global de personalidad y de regulación emocional, los resultados revelaron dos subgrupos de estudiantes con diferentes niveles de satisfacción académica consistentes desde un punto de vista conceptual y empírico. Se discuten las implicaciones y limitaciones del estudio.

Key Words:

Emotion regulation; personality traits; academic satisfaction; undergraduate.

Palabras Clave:

Regulación emocional; personalidad; estudiantes universitarios.

\footnotetext{
Đ Mario Trogolo, Lic. en Psicología. Laboratorio de Psicología Cognitiva. Facultad de Psicología, Universidad Nacional de Córdoba. Enfermera Gordillo esquina Enrique Barros, Ciudad Universitaria. Córdoba, Argentina. Dirección: Avda. Colón 870, planta baja, departamento 4. Teléfono: 540351-4241451, E-Mail: mariopsicounc@gmail.com
} 


\section{INTRODUCTION}

Psychological practices in the school have traditionally focused on diagnosing children and adolescents with learning disabilities, counseling for parents with troubled children and educational advice activities. Less frequently, special prevention programs have been implemented to respond to specific problems such as violence, drug or alcohol abuse (Castro, 2010). In this sense, interventions in schools have followed a reactive model based on problems and disturbance, while little attention has been paid to reinforcing positive behaviors or promoting positive qualities in both students who have problems and those who do not in order to enhance their well-being (Terjesen, Jacofsky, Froh \& DiGiuseppe, 2004).

In line with this, recently several authors emphasized the need to move toward a positive education, attending not only traditional skills of students but also their well-being, that is, including the skills that promote well-being (Seligman, Ernst, Guillham, Reivich\&Linkins, 2009). As the authors explain, focus on well-being does not imply neglect the traditional goals on education; rather, it reinforces them. Indeed, more well-being and better learning are synergistic.

In the context of higher education, the study of well-being, their antecedents and correlates has become a topic of extensive research over last decade (e.g., Cha 2003; Harrington \&Lofredo, 2001; Kaplan \&Maehr, 1999; Wang \& Castaneda-Sound, 2008). A more focused line of inquiry in this scope concerns the issue of academic satisfaction, which is defined as enjoyment of one's role or experiences as a student (Lent \& Brown, 2008). Existing literature suggests that academic satisfaction is a core variable on behavior and academic functioning of students. More specifically, it has been found positive relationships between academic satisfaction and academic adjustment (Lent, Taveira, Sheu\& Single, 2009), engagement (Wefald\& Downey, 2009), performance (Caballero, Abello\& Palacio, 2007), goal orientation (Roebken, 2007) and life satisfaction of students (Lounsbury, Park, Sundstrom, Williamson \& Pemberton, 2004), as well as albeit negatively with academic failure (Lounsbury et al., 2003), burnout (Salanova, Martínez, Bresó, Llorens\&Grau, 2005), absenteeism and intention to dropout (Schmitt, Osvald, Friede, Imus \& Merritt, 2008). As pointed by Benjamin and Hollings (1997), student satisfaction is a key variable because it appears related to a number of other variables in which educators posit great value.
According to empirical research academic satisfaction is influenced by numerous factors, including advising, course offerings, career preparation, instruction, social support, self-efficacy and goal progress (Corts, Lounsbury, Saudargas\& Tatum, 2000; Lent et al., 2005; Sanders \& Burton, 1996). From a top down approach, recently Lounsbury, Saudargas, Gibson \& Leong (2005) found that personality factors accounted for $40 \%$ of the variance in academic satisfaction, suggesting that this variable is a particularly strong predictor of student satisfaction. Consequently, the present study assessed personality traits in relation to academic satisfaction.

Another growing field of study who has garnered attention by researchers from different areas concerns to strategies that individuals use to manage their emotions, which is known as emotion regulation. According to Gross (1998), emotion regulation encompasses "the processes by which individuals influence which emotions they have, when they have them, and how they experience and express these emotions" (p. 275). As such, emotion regulation involves various processes such as monitoring, evaluating, and modifying one's emotional experiences (Thompson, 1994).

The ability to regulate emotions is crucial for emotional intelligence (Gross \& John, 2002; Salovey\& Mayer, 1990). Contemporary researchers agree that people engage in some form of emotion regulation almost all the time and that these efforts can be triggered by hedonic (i.e., feel pleasure and avoid pain; Larsen, 2000); instrumental (i.e., specific goal pursuits; Tamir, 2009) and sociocultural goals (e.g., display rules; Mesquita\& Albert, 2007). Such emotion regulatory efforts can be automatic or controlled, and increase, maintain or decrease positive and negative emotions (Masters, 1991; Parrott, 1993).

Based on theoretical and empirical approaches, Gratz and Roemer (2004) proposed an integrative model of emotion regulation. According to the model, emotion regulation can be conceived as a set of different, albeit interrelated, abilities including emotional awareness, emotional clarity, emotional acceptance, impulse control, ability to engage in desired goals while experiencing negative emotion and the ability to use flexibly and situationally appropriate strategies to modulate emotional responses as desired. The relative absence of any or all of these abilities would indicate the presence of difficulties in emotion regulation. 
Accumulate research indicates that emotion regulation abilities are central to mental health; they can either support or disrupt the capacity to work, relate to others and enjoy oneself (Gross \& Muñoz, 1995). In the academic domain, past research has shown positive associations between emotion regulation and school performance (Gumora\&Arsenio, 2002), and negative relations with behavior problems and trouble learning (Graziano, Reavis, Keane \& Calkins, 2007). It should be noted, however, that most studies on emotion regulation have conducted with kindergarten, elementary and middle school students. In the higher education setting, research on emotion regulation has focused primarily on teachers (e.g., Barber, Grawitch, Carson \&Tsouloupas, 2011; Brackett,Palomera, Mojsa-Kaja, Reyes \&Salovey, 2010; Sutton, 2004; Sutton \& Harper, 2009; Sutton, Mudrey-Camino \& Knight, 2009) and relatively few empirical studies have examined emotion regulation abilities among college students (e.g., Lopes, Salovey, Beers \&Côté, 2005; Schutz, Distefano, Benson \& Davis, 2004). Moreover, no investigation has explicitly tested the role of such abilities on academic satisfaction. Accordingly, in the present study we assessed emotion regulation in relation to academic satisfaction.

Based on prior findings and assumptions, the following hypotheses were proposed:

H1) Big Five traits of neuroticism, extraversion, agreeableness, conscientiousness and openness are significantly related to academic satisfaction.

H2) Difficulties in emotion regulation (i.e., lack of emotional awareness, lack of emotional clarity, nonacceptance of emotional responses, impulse control difficulties, difficulties engaging in goaldirected behavior and limited access to emotion regulation strategies) are significantly related to academic satisfaction.

H3) Big Five traits significantly predict academic satisfaction.

H4) Difficulties in emotion regulation contribute uniquely to the prediction of academic satisfaction above and beyond the Big Five personality traits.

\section{METHOD}

\subsection{Participants}

Participants were 230 undergraduates (73.5\% women, $26.5 \%$ men) from different careers at a single, large university of Cordoba, Argentina. Specifically, the sample included students from Psychology (42.6\%), Agronomy (11.3\%), Economy (16.1\%), Chemistry (8.7\%) and Nutrition (21.3\%). Fifty-eight per cent of the participants were freshmen;
9\%, sophomores; $13 \%$, juniors; and 20\%, seniors. Their mean age was $20.56, D S=3.67$.

\subsection{Procedure}

Data were collected during regular class hours over a week. After requesting teachers for permission and explained to students the general purpose of the study, they were asked to participate voluntarily and no incentives were offered for participation. All participants completed measures of personality, emotion regulation and academic satisfaction. Additionally, demographic and academic information (e.g., gender, year in college, career) was obtained on a background questionnaire. Finally, data analysis was carried out using SPSS 17.0.

\subsection{Measures}

Personality.Personality was assessed with the IPIP-NEO 120 personality inventory (Cupani, 2012). It consists of 120 items, self-report measure that evaluates the Big Five personality traits of extraversion, neuroticism, agreeableness, conscientiousness and openness, and specific facets of each trait. Respondents are asked to indicate how much they agreed which each statement, from 1 (strongly disagree with this description of myself) to 5 (strongly agree with this description of myself).

The Five Factor Model, commonly known as the "Big Five", represent a parsimonious theoretical framework for personality that possess decades of factorial analysis on samples of different ages and gender in different cultures (Costa \& McCrae, 1999). The overall factor structure and construct validity of the Big Five Model has been extensively demonstrated across different settings in individuals with different demographic and cultural characteristics (Costa \& McCrae 1994; De Raad, 2000).

Taking into account the low reliability of many facets, in the current study we only assessed the Big Five traits. Alpha coefficients for the subscales ranged from .84 to .87 .

Difficulties in Emotion regulation. To assess emotion regulation, the Difficulties in Emotion Regulation Scale (DERS) initially developed by Gratz and Roemer (2004) and validated in argentine undergraduate population (Medrano \&Trógolo, 2012) was used. The DERS is a 36-items, self-report measure that assesses difficulties within different but interrelated abilities of emotional regulation: (a) lack of emotional awareness $(\alpha=.71)$ : it consists of items reflecting the tendency to attend to and acknowledge 
emotions. All items are reverse-scored (e.g., "I am attentive to my feelings"); (b) lack of emotional clarity $(\alpha=.70)$ : it is composed of items reflecting difficulties to know and be clear about the emotions that individuals are experiencing (e.g., "I am confused about how I feel'); (c) nonacceptance of emotional responses $(\alpha=.84)$ : it is composed of items that reflect the tendency to experience negative secondary emotional reactions in response to a primary negative emotion (e.g., "When I'm upset, I feel guilty for feeling that way"); (d) difficulties engaging in goal-directed behavior $(\alpha=.82)$ : it is comprised of items reflecting difficulties in concentrating and accomplishing tasks when experiencing negative emotions (e.g., "When I'm upset, I have difficulty getting work done"); (e) impulse control difficulties $(\alpha=.87)$ : it is composed of items reflecting difficulties in controlling one's behavior when experiencing negative emotions (e.g., "When I'm upset, I feel out of control".); and ( $\mathrm{f}$ ) limited access to emotion regulation strategies $(\alpha=.54)$ : it consists of items reflecting the belief that there is little that can be done to modify an unpleasant emotional state (e.g., "When I'm upset, I believe that there is nothing I can do to make myself feel better"). Participants are asked to indicate how often the items apply to themselves, using a five-point Likert scale, from 1 (almost never) to 5 (almost always).

Academic Satisfaction.Academic satisfaction was assessed with a 8-items scale asking participants to indicate the degree to which they felt satisfied with different aspects of their academic experience (e.g., "Classes are interesting"; "I am satisfied with the course"). Participants responded to each item using a four-point Likert scale from 0 (never) to 3 (always).

The scale was originally developed by Sisto et al. (2008) and adapted in argentine undergraduate population by Medrano and Pérez (2010). Psychometric studies using exploratory factorial analysis yielded an internal structure of a single dimension which explained $48 \%$ of the variability. The alpha coefficient for the scale was .84.

\section{RESULTS}

Table 1 presents the descriptive statistics and the correlation matrix for Big Five traits, difficulties in emotion regulation and academic satisfaction variables. As shown in the table, neuroticism was negatively and significantly related to academic satisfaction $(r=-.15 ; \quad p<.05)$. Conscientiousness also correlated significantly but positively with academic satisfaction $(r=.20 ; p<.01)$. On the contrary, no significant relationships were found between academic satisfaction and extraversion ( $r=.10, p=.13$ ), agreeableness ( $r=.05$, $p=.46)$ and openness ( $r=.06, p=.38)$.

Regarding difficulties in emotional regulation, only lack of emotional clarity was significantly related to academic satisfaction $(r=-.16 ; p<.05)$. Lack of emotional awareness, nonacceptance of emotional responses, impulse control difficulties, difficulties engaging in goal-directed behavior and limited access to emotion regulation strategies did not show significant relationships with academic satisfaction $(r=.07, p=.28 ; r=-.07, p=.31 ; r=-.06, p=.34 ; r=-.06$ $. p=.35 ; r=-.11, p=.09$; respectively).

To assess the third and fourth hypotheses, a multiple regression analysis was performed with two hiercarchical steps: in the first step, big five personality traits of extraversion, neuroticism, agreeableness, conscientiousness and openness were entered. In the second step, deficits in emotion regulation skills -lack of emotional awareness, lack of emotional clarity, nonacceptance of emotional responses, impulse control difficulties, difficulties engaging in goal-directed behavior and limited access to emotion regulation strategies- were added as predictors (Table 2). Following recommendations concerning the application of multivariate statistical techniques (Tabachnick\&Fidell, 2001), before to running the analysis we examined data for the absence of outliers and the assumptions of normality, linearity, homocedasticity and multicollinearity.

As can be seen in Table 2, none of the Big Five personality traits contributed significantly to the prediction of academic satisfaction in undergraduates; $R^{2}=.038, F(5,171)=1.34, p=.25$. When difficulties in emotion regulation were entered into the equation, no significant increase of the variance in academic satisfaction was observed; $R^{2}=.005, F(6,165)=0.16, p=.98$.

Cluster analysis: profiles of students according topersonality traits, difficulties inemotionregulation andacademic satisfaction

It could be possible that analytic methods applied in this study don't allow us to capture adequately the role of personality traits and difficulties in emotion regulation on academic satisfaction. Consequently, we decided to re-analyze data using cluster analysis, an effective analytic technique that helps researchers to identify groups of individuals with similar characteristics, especially when examining multiple constructs of interest (Borgen\& Barnett, 1987). Cluster analysis has also been suggested as a useful technique to identify relationships (Hair, Anderson, Tatham\& Black, 1999). 
Table 1.Descriptive statistics and intercorrelations among variables

\begin{tabular}{|c|c|c|c|c|c|c|c|c|c|c|c|c|}
\hline Variables & 1 & 2 & 3 & 4 & 5 & 6 & 7 & 8 & 9 & 10 & 11 & 12 \\
\hline 1. Neuroticism & - & $-.36^{\star *}$ & -.05 & -.10 & $-.41^{\star \star}$ & $-.15^{\star}$ & $.49^{\star *}$ & $.40^{\star *}$ & $.39^{\star \star}$ & $.43^{\star \star}$ & $.50^{\star \star}$ & $-.17^{\star}$ \\
\hline 3. Openness & & & - & $.19^{* *}$ & -.10 & $.29^{\star \star}$ & -.11 & -.04 & -.07 & .05 & $-.24^{\star *}$ & .06 \\
\hline 4. Agreeableness & & & & - & $.16^{\star}$ & .09 & $-.15^{*}$ & $-.22^{\star \star}$ & -.06 & -.10 & -.13 & .05 \\
\hline \multicolumn{13}{|l|}{ DERS } \\
\hline $\begin{array}{l}\text { 6. Lack of } \\
\text { emotionalawareness }\end{array}$ & & & & & & - & $-.22^{\star \star}$ & -.03 & -.04 & $-.14^{*}$ & -.12 & .07 \\
\hline 7. Lack of emotional clarity & & & & & & & - & $.27^{\star \star}$ & $.28^{\star \star}$ & $.33^{\star \star}$ & $.34^{\star \star}$ & $-.16^{\star}$ \\
\hline 8. Impulse control difficulties & & & & & & & & - & $.54^{\star \star}$ & $.55^{\star \star}$ & $.42^{\star \star}$ & -.06 \\
\hline $\begin{array}{l}\text { 11. Limited access to emotion } \\
\text { regulation strategies }\end{array}$ & & & & & & & & & & & - & -.11 \\
\hline 12. Academic satisfaction & & & & & & & & & & & & - \\
\hline M & 69.97 & 83.18 & 82.23 & 90.53 & 82.54 & 14.36 & 10.30 & 12.70 & 16.06 & 13.01 & 6.57 & 14.36 \\
\hline$S D$ & 11.49 & 9.32 & 9.86 & 9.64 & 10.06 & 3.15 & 3.37 & 5.38 & 4.87 & 5.68 & 2.51 & 3.35 \\
\hline
\end{tabular}

${ }^{\star} p<.05,{ }^{\star \star} p<.01$

Table 2.Results of multiple regression analysis for Big Five traits and difficulties in emotion regulation in predicting academic satisfaction

\begin{tabular}{|c|c|c|c|c|c|}
\hline Steps & Variables & Multiple $R$ & $R^{2}$ & $R^{2}$ Change & Sig. \\
\hline 1 & $\begin{array}{l}\text { Big Five traits (neuroticism, extraversion, openness, } \\
\text { agreeableness and conscientiousness) }\end{array}$ & .194 & .038 & .038 & .251 \\
\hline 2 & $\begin{array}{l}\text { Difficulties in emotion regulation (lack of emotional } \\
\text { awareness, lack of emotional clarity, nonacceptance } \\
\text { of emotional responses, difficulties engaging in goal- } \\
\text { directed behavior, impulse control difficulties, limited } \\
\text { access to emotion regulation strategies) }\end{array}$ & .208 & .043 & .005 & .987 \\
\hline
\end{tabular}

A nonhierarchical $k$-means cluster analysis was performed. Two, three and four cluster solutions were initially specified. The final solution selected was comprised of two clusters, attending to different criteria: first, two clusters were the most parsimonious solution, and secondly, this solution allows us to identify profiles of students clearly interpretable from both conceptual and empirical perspective. In particular, cluster 1 ( $n=115)$ was characterized by students with higher extraversion, agreeableness, conscientiousness, openness, emotional awareness, and lower levels of neuroticism, lack of emotional clarity, nonacceptance of emotional responses, impulse control difficulties, difficulties engaging in goal-directed behavior and limited access to emotion regulation strategies. The second cluster $(n=63)$ was comprised of students with a completely opposite personality and emotion regulation profile, that is, students with lower levels in emotional awareness, extraversion, agreeableness, conscientiousness and openness, as well as higher levels in neuroticism, lack of emotional clarity, nonacceptance of emotional responses, impulse control difficulties, difficulties engaging in goal- 
directed behavior and limited access to emotion regulation strategies (Figure 1 ).

Further comparisons revealed that students from cluster $1(M=14.74, S D=3.28)$ have significantly higher levels of academic satisfaction than those from cluster $2(M=13.31 ; D S=3.27$; $t(175)=-2.79, p<.05$. Cohen's $d=.44)$

Figure 1.Profiles of students according to personality and difficulties in emotion regulation

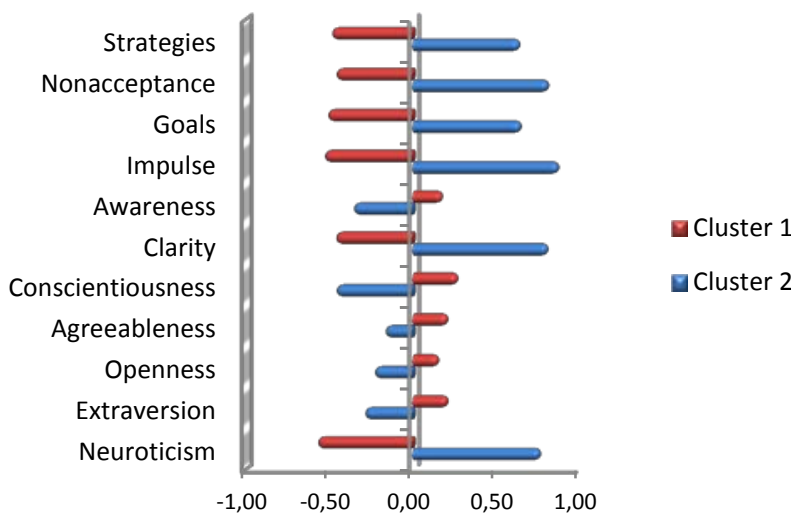

Note:STRATEGIES: limited access to emotion regulation strategies; NONNACEPTANCE: nonnaceptance of emotional responses; GOALS: difficulties in engaging goal-directed behavior; IMPULSE: impulse control difficulties; AWARENESS: emotional awareness; CLARITY: lack of emotional clarity

\section{DISCUSSION}

In this research, the relationships between personality, difficulties in emotion regulation, and academic satisfaction were studied. The predictive capacity of personality traits and difficulties in emotion regulation on academic satisfaction was also analyzed.

In partial support of our first hypothesis, $\mathrm{H} 1$, we found that neuroticism and conscientiousness were related as expected to academic satisfaction. According to these findings, students low in neuroticism and high in conscientiousness expressed more satisfaction with their academic experience. Contrary to previous study (Lounsbury et al., 2005), neither agreeableness nor openness were associated to academic satisfaction reported by undergraduates.

Regarding the hypothesis about the relationships between difficulties in emotion regulation and academic satisfaction, $H 2$, was weakly supported. Indeed, we found that only lack of emotional clarity was negatively related to academic satisfaction, indicating that students with less difficulties to differentiate their emotions report greater satisfaction in the academic domain.

In contrast to predicted in $\mathrm{H} 3$ and earlier findings (Lounsbury et al., 2005), personality traits did not contribute to predict academic satisfaction. This discrepancy could have been due to the fact that we measured personality traits based on Big Five Model and not included narrow traits, such as optimism and self of identity, which were the most salient predictors of academic satisfaction reported by Lounsbury and his colleagues.

The last hypothesis analyzed, $\mathrm{H} 4$, was also not confirmed by empirical data. Thus, difficulties in emotion regulation not appear to be an important variable in predicting academic satisfaction.

If one were to follow the usual interpretation of such results, one would conclude from the present study that personality traits and emotion regulation of college students have little to do in their academic satisfaction. Nevertheless, results from cluster analysis suggest the opposite, since two students group with substantially different profiles of personality and emotion regulation were identified: the first, "more satisfied" group included students with lower neuroticism, higher extraversion, agreeableness, conscientiousness, openness and ability to regulate their emotions (i.e., higher levels of emotional awareness, and lower levels of lack of emotional clarity, nonacceptance of emotional responses, impulse control difficulties, difficulties engaging in goal-directed behavior and limited access to emotion regulation strategies). The second, "less satisfied" group was comprised of students who reported elevated levels of neuroticism and difficulties in emotion regulation (i.e., lower levels of emotional awareness, and higher levels of lack of emotional clarity, nonacceptance of emotional responses, impulse control difficulties, difficulties engaging in goal-directed behavior and limited access to emotion regulation strategies) along with lower levels of extraversion, agreeableness, conscientiousness and openness.

Keeping with these results, we argue that it might be better to understand the role of personality traits and emotion regulation abilities considering them collectively rather than individually; in other words, attending to the global profiles of personality or emotion regulation. Regarding emotion regulation, it seems possible that students could regulate their emotions adaptively even when having deficits on a single ability. By way of example, in face of anxiety it might occurs that a student would have difficulties in recognizing her/his emotions but not interference in 
engaging goal-directed behavior or difficulties in regulating impulsive behavior. In this way, we contend that only students who systematically have deficits on various emotion regulation abilities will experience less academic satisfaction, or the reverse, as suggested by classification emerged from clustering.

Analogous considerations can be made for personality traits. That is, we suggest that certain personality profiles, rather than specific personality traits in isolation, would provide a better explanation of students' academic satisfaction.

Correlation analysis and profiles derived from cluster analysis also indicates linkages among personality traits and emotion regulation. The relationships between stable personality traits and emotion regulation processes have been welldocumented. For example Davies, Stankov and Roberts (1998) found that extraversion correlated positively and neuroticism negatively with repair. Openness has been correlated with the ability to recognize emotions (Terracciano, Merritt, Zonderman\& Evans, 2003); and agreeableness has been related to how individual express negative emotions (McCrae \& Costa, 1997).

In an effort to understand the relationships between personality and emotion regulation, Kokkonen and Pulkkinen (2001) investigated the mediational effect of mood and its evaluation. They conclude that relations between personality and emotion regulation strategies are mainly indirect, suggesting that personality make people more vulnerable to certain moods, which in turn are evaluated differently and lead to adopt different emotion regulation strategies. According to these findings, including a mediation approach could be potentially useful to clarify how personality and emotion regulation interact to predict academic satisfaction.

From a practice perspective, the present findings suggest some directions for interventions or programs trough academic satisfaction may be fostered. Based on personality traits, previously Lounsbury et al. (2005) proposed useful routes for interventions involving different programmatic areas such as orientation, career planning program, residence hall placement, and interventions aimed to increase trait levels or person-environment fit.

Current results also raise the possibility that students-training programs focusing on developing emotion regulation skills may be helpful in promoting academic satisfaction. Prior research (Trógolo\& Medrano, 2011)found that students who experience more positive emotions are prone to feel more satisfied in academic domain, while -interestinglynegative emotional states did not associate with academic satisfaction reported by students. Following these results, it would valuable for interventions to focus on strategies aimed at maintaining and increasing experiences of positive emotions.

Interpretation and application of these findings should be considered in the context of the study's limitations. First, variables were analyzed using a cross-sectional design. Such design is useful in exploring concurrent relations among variables but is not able to test temporal relations; longitudinal studies would allow to examine how emotion regulation and personality influence on academic experience and, conversely, how academic experience influences on those variables. In this regard, as Lounsbury et al. (2005) posited, there is much variability on personality traits during years college and it seems possible that academic experience influence on personality traits; for example, by selecting environments and participating in situations that impacts on students' level traits. Moreover, it seems feasible that as result of their college experience students learn to regulate emotions more effectively, preferring certain strategies to others.

A second limitation refers to the sample used in this study. Participants recruited were predominantly freshmen and women from a single state university. For this reason, a broader sample of colleges including comparable proportions of man and women from diverse careers and years in college would allow researchers to examine whether current findings are generalizable across different demographic subgroups characterized by the type of college attended, gender, major, year in college, among others.

A third limitation concerns to the data analytic method used in this study. As pointed by Hair et al. (1999), cluster analysis is a descriptive, non-inferential analytic technique so inferences cannot be drawn. Thus, present findings are limited in scope and future research is needed to determine whether results can be extended to other samples of college students.

Fourth, although the current study suggests that emotion regulation and academic satisfaction are related, we cannot infer causality and mechanisms explaining why it occurs are unknown. Nonetheless, based on empirical findings several conjectures can be formulated. More precisely, 
Lopes et al. (2005) demonstrated that students' emotion regulation abilities influence on the quality of social interaction with their peers, even after controlling for personality traits. Moreover, Trógolo and Medrano(2011, Agosto) found that students with higher abilities to regulate their emotions experienced high positive emotions and low negative ones. Along with these results, ample research findings have confirmed that emotions are vital for self-regulation (Baumeister, Zell \& Tice, 2007), which may suggest that emotion regulation abilities have an important role on students' self-regulation behavior, such as managing stress and progress toward their goals. In light of empirical findings and suppositions listed above, we conjecture that students with higher emotion regulation abilities may be more capable at generating positive emotions, undoing negative emotions, building social support, dealing with stress and making progress toward their goals, which in turn may lead to academic satisfaction. For future research, it would great value to test the possible mediational effects of these variables between emotion regulation abilities and academic satisfaction, which could contribute to understand how emotion regulation affect (i.e., directly or indirectly) academic satisfaction.

Fifth, the current study was exclusively focused on processes within individuals and external variables were not taken into account. However, previous studies revealed that features of the environment influence on academic satisfaction (e.g., Corts et al., 2000; Lent et al., 2005; Sanders \& Burton, 1996). From this perspective, many questions could be addressed. Specifically, how do external variables (e.g., academic workload, teacher support, massiveness, faculty services, institutional disorganization) and emotion regulation interact to predict academic satisfaction? Further research should address these questions by examining jointly these variables in relation to academic satisfaction.

A sixth limitation derives from measures used. Particularly, emotion regulation as measured by DERS, is focus primarily on the regulation of negative emotional states (Gratz\& Roemer, 2004). Therefore, future research may want to assess the regulation (i.e., downward, maintenance and upward) of positive emotional states as well, and how its impact on students' satisfaction with their academic experience.

Despite all limitations, results of the current study are promising as they provide initial evidence of the links between emotional regulation and academic satisfaction. Future research endeavors in this arena will shed light on the nature and mechanisms underlying the linkages between these constructs.

\section{REFERENCES}

Barber, L., Grawitch, M., Carson, R.\&Tsouloupas, C. (2011).Costs and benefits of supportive versus disciplinary emotion regulation strategies in teachers.Stress and Health, 27,173-187.

Baumeister, R., Zell, A.\& Tice, D. (2007). How emotions facilitate and impair self-regulation. In Gross, J.J. (Ed.), Handbook of Emotion Regulation (pp. 408-426). New York: Guilford Press.

Benjamin, M.\& Hollings, A. (1997). Student satisfaction: Test of an ecological model. Journal of College Student Development, 38, 213-228.

Borgen, F.\& Barnett, D. (1987).Applying cluster analysis in counseling psychology research.Journal of Counseling Psychology, 34, 456-468.

Brackett, M., Palomera, R., Mojsa-Kaja, J., Reyes, M.\&Salovey, P. (2010).Emotion-regulation ability, burnout, and job satisfaction among British secondary-school teachers.Psychology in the Schools, 47, 406417.

Caballero, C., Abello, R.\& Palacio, J. (2007).Relación del burnout y el rendimiento académico con la satisfacción frente a los estudios en estudiantes universitarios. Avances en Psicología Latinoamericana, 25,98-111.

Castro, A. (2010). Fundamentos de Psicología Positiva. Buenos Aires: Paidós.

Cha, K. (2003). Subjective well-being among college students.Social Indicators Research, 62, 455-477.

Corts, D., Lounsbury, J., Saudargas, R.\& Tatum, H. (2000).Assessing undergraduate satisfaction with an academic department: a method and case study.College Student Journal, 34, 399408.

Costa, P.\& McCrae, R. (1994). Stability and change in personality from adolescence through adulthood. In: Halverson, C. F. Jr, Kohnstamm, G. A., and Martin, R. P. (Eds.), The Developing Structure of Temperament and Personality from Infancy to Adulthood (pp. 139-155). Erlbaum: Hillsdale.

Costa, P.\&McCrae, R. (1999). Inventario de Personalidad NEO Revisado. Madrid: TEA

Cupani, M. (2012). Adaptación del inventario IPIPNEO 120 a la población de estudiantes universitarios de Córdoba. Manuscript unpublished.

Davies, M., Stankov, L.\& Roberts, R. (1998). Emotional intelligence: In search of an 
elusive construct. Journal of Personality and Social Psychology 75, 989-1015.

De Raad, B. (2000). The Big Five personality factors (The psycholexical approach to personality). Seattle, USA: Hogrefe\& Huber.

Gratz, K. L.\&Roemer, L. (2004).Multidimensional assessment of emotion regulation and dysregulation: development, factor structure, and initial validation of the difficulties in emotion regulation scale. Journal of Psychopathology and Behavioral Assessment, 26, 41-54.

Graziano, P., Reavis, R., Keane, S.\& Calkins, S. (2007). The role of emotion regulation in children's early academic success.Journal of School Psychology, 45, 3-19.

Gross, J. \& Muñoz, R. (1995). Emotion regulation and mental health.Clinical Psychology: Science and Practice, 2, 151-164.

Gross, J. (1998). The emerging field of emotion regulation: An integrative review. Review of General Psychology,2, 271-299.

Gross, J.\& John, O. (2002). Wise emotion regulation. In L. Feldman Barrett \& P. Salovey (Eds.), The wisdom in feeling: Psychological processes in emotional intelligence (pp. 297319). New York, USA: Guilford Press.

Gumora, G.\&Arsenio, W. (2002).Emotionality, emotion regulation, and school performance in middle school children.Journal of School Psychology, 40, 395-413.

Hair, J., Anderson, R., Tatham, R.\& Black, W. (1999).Análisis Multivariante. Madrid, España: Prentice Hall.

Harrington, R.\&Lofredo, D. A. (2001). The relationship between life satisfaction, selfconsciousness, and the Myers-Briggs type inventory dimensions. The Journal of Psychology, 135, 439-450.

Kaplan, A.\&Maehr, M. (1999).Achievement goals and student well-being.Contemporary Educational Psychology, 24,330-358.

Kokkonen, M.\&Pulkkinen, L. (2001). Examination of the paths between personality, current mood, its evaluation, and emotion regulation.European Journal of Personality, $15,83-104$.

Larsen, R. (2000). Toward a science of mood regulation.Psychological Inquiry, 11, 129141.

Lent, R.\& Brown, S. (2008). Social cognitive career theory and subjective well-being in the context of work.Journal of Career Assessment, 16, 6-21.

Lent, R., Singley, D., Sheu, H., Gainor, K., Brenner, B., Treistman, D.\&Ades.L. (2005). Social cognitive predictors of domain and life satisfaction: Exploring the theoretical precursors of subjective well-being. Journal of Counseling Psychology, 52,429-442.

Lent, R., Taveira, M., Sheu H.\& Single, D. (2009). Social cognitive predictors of academic adjustment and life satisfaction in Portuguese college students: A longitudinal analysis. Journal of Vocational Behavior, 74, 190-198.

Lopes, P., Salovey, P., Beers, M.\&Côté, S. (2005). Emotion regulation abilities and the quality of social interaction.Emotion, 5, 113-118.

Lounsbury, J., Loveland, J., Sundstrom, E., Gibson, L., Drost, A.\& Hamrick, F. (2003).An investigation of personality traits in relation to career satisfaction.Journal of Career Assessment, 11, 287-307.

Lounsbury, J., Park, S., Sundstrom, E., Williamson, J. \& Pemberton, A. (2004). Personality, career satisfaction and life satisfaction: test of a directional model. Journal of Career Assessment, 12, 395-406.

Lounsbury, J., Saudargas, R., Gibson, L.\& Leong, F. (2005).An investigation of broad and narrow personality traits in relation to general and domain-specific life satisfaction of college students.Research in Higher Education, 46, 707-729.

Masters, J. (1991). Strategies and mechanisms for the personal and social control of emotion.In Garber, J.\& Dodge, K.A. (Eds.), The development of emotion regulation and dysregulation(pp.182-207). Cambridge, England: Cambridge University Press.

McCrae, R. \& Costa, P. (1997). Personality traits structure as a human universal. American Psychologist, 52, 509-516.

Medrano, L. \&Trógolo, M. (2012). Análisis Factorial Confirmatorio de la Escala de Dificultades en la Regulación Emocional (DERS). Resumen publicado en las Memorias del IV Congreso Regional de la sociedad Interamericana de Psicología (SIP).

Medrano, L.A.\& Pérez, E. (2010). Adaptación de la escala de satisfacción académica a la población universitaria de Córdoba. Summa Psicológica UST, 7, 5-14.

Mesquita, B.\& Albert, D. (2007).The cultural regulation of emotions. In Gross, J. J. (Ed.), Handbook of Emotion Regulation (pp. 486503). New York, USA: Guilford Press.

Parrott, W.G. (1993). Beyond hedonism: Motives for inhibiting good moods and for maintaining bad moods. In Wegner, D.M.\&Pennebaker, J.W. (Eds.), Handbook of mental control (pp. 278-308). Englewood Cliffs, NJ: PrenticeHall. 
Roebken, H. (2007). The influence of goal orientation on student satisfaction, academic engagement and achievement.Electronic Journal of Research in Educational Psychology, 13, 679-704.

Salanova, M., Martínez, I., Bresó, .E, Llorens.S.\& Grau, R. (2005). Bienestar psicológico en estudiantes universitarios: facilitadores y obstaculizadores del desempeño académico. Anales de Psicología, 21, 170-180.

Salovey, P.\& Mayer, J. D. (1990).Emotionalintelligence.Imagination, Cognition, and Personality, 9, 185-211.

Sanders, L.\& Burton, J. D. (1996). From retention to satisfaction: new outcomes for assessing the freshman experience. Research in Higher Education, 37, 555-567.

Schmitt, N., Oswald, F., Friede, A., Imus, A.\& Merritt, S. (2008). Perceived fit with an academic environment: Attitudinal and behavioral outcomes. Journal of Vocational Behavior, 72, 317-335.

Schutz, P., Distefano, C., Benson, J.\& Davis, H. (2004). The emotional regulation during testtaking scale.Anxiety, Stress, and Coping, 17, 253-269.

Seligman, M., Ernst, R., Guillham, J., Reivich, K., \&Linkins, M. (2009). Positive education: Positive Psychology and classroom interventions. Oxford Review of Education, 35, 293-311.

Sisto, F., Muniz, M., Bartholomeu, D., Vítola, N., Oliveira, A.\& Guimarães, W. (2008). Estudopara a construção de uma escala de satisfaçãoacadêmica para universitários. AvaliaçãoPsicológica, 7, 45-55.

Sutton, R. (2004). Emotional regulation goals and strategies of teachers.Social Psychology of Education, 7, 379-398.

Sutton, R., \& Harper, E. (2009).Teachers' emotion regulation.In Saha, L. J. \&Dworkin, A. G. (Eds.), The new international handbook of teachers and teaching (pp. 389-401). New York, USA: Springer.

Sutton, R., Mudrey-Camino, R.\& Knight, C. (2009).Teachers' emotion regulation and classroom management.Theory into Practice, 48, 130-137.

Tabachnick, B.\&Fidell, L. (2001). Using multivariate statistics. New York, USA: Harper \& Row.

Tamir, M. (2009). What do people want to feel and why? Pleasure and utility in emotion regulation.Current Directions

Psychological Science, 18, 101-105.

Terjesen, M., Jacofsky, M., Froh, J., \&DiGiuseppe, R. (2004).Integrating positive psychology into schools: Implications for practice.Psychology in the schools 41, 163-172.

Terracciano, A., Merritt, M., Zonderman, A.\& Evans, M. (2003).Personality traits and sex differences in emotion recognition among African Americans and Caucasians.Annals of the New York Academy of Sciences, 1000, 309-312.

Thompson, R. (1994). Emotion regulation: A theme in search of definition. Monographs of the Society for Research in Child Development, 59, 25-52.

Trógolo, M. y Medrano, L. (2011).Regulación de la Emociones en estudiantes universitarios: su contribución en el comportamiento académico. Revista Argentina de Ciencias del Comportamiento, Suplemento, 39.

Trógolo, M. \& Medrano, L. (2011, Agosto).Regulación de las emociones en estudiantes universitarios: su contribución al comportamiento académico positivo. XIII Reunión Nacional, II Encuentro Internacional de la Asociación Argentina de Ciencias del Comportamiento, Entre Ríos, Argentina. Revista Argentina de CienciasdelComportamiento.SuplementoNov iembre, 13-58.

Wang, C.\&Castañeda-Sound, C. (2008). The role of generational status, self-esteem, academic self-efficacy, and perceived social support in college students' psychological wellbeing.Journal of College Counseling, 11, 101-118.

Wefald, A.\& Downey, R. (2009). Construct dimensionality of engagement and its relation with satisfaction. The Journal of Psychology, 143, 91-111. 